The Center for Migration and Development
Working Paper Series. Princeton University

Revisiting the Enclave Hypothesis:

Miami Twenty-Five Years Later

\author{
by \\ Alejandro Portes \\ and \\ Steven Shafer \\ Princeton University
}

May 2006

CMD Working Paper \#06-10 


\title{
Revisiting the Enclave Hypothesis: Miami Twenty-Five Years Later*
}

\author{
by \\ Alejandro Portes \\ and \\ Steven Shafer \\ Princeton University
}

May 2006

*Paper originally presented at the Conference on New Directions in Equality and Stratification. Princeton University, April 6-8, 2006. We acknowledge the very helpful commentaries on the original version by Philip Kasinitz, Patricia Fernandez-Kelly, and Min Zhou. Responsibility for the contents is exclusively ours. 


\begin{abstract}
We review the empirical literature on ethnic economic enclaves after the concept was formulated twenty-five years ago. The balance of this literature is mixed, but many studies reporting negative conclusions were marred by faulty measurement of the concept. We discuss the original theoretical definition of enclaves, the hypotheses derived from it, and the difficulties in operationalizing them. For evidence, we turn to census data on the location and the immigrant group that gave rise to the concept in the first place - Cubans in Miami. We examine the economic performance of this group, relative to others in this metropolitan area, and in the context of historical changes in its own mode of incorporation. Taking these changes into account, we find that the ethnic enclave had a significant economic payoff for its founders - the earlier waves of Cuban exiles - and for their children, but not for refugees who arrived in the 1980 Mariel exodus and after. Reasons for this disjuncture are examined. Implications of these results for enclave theory and for immigrant entrepreneurship in general are discussed.
\end{abstract}




\section{Revisiting the Enclave Hypothesis: Cuban Miami Twenty-Five Years Later}

In 1980, Wilson and Portes published an article in the American Journal of Sociology, that identified ethnic enclaves as a distinct form of economic adaptation. These formations were characterized by the spatial concentration of immigrants who organize a variety of enterprises to serve their own market as well as the general population. A substantial proportion of workers of the same nationality were employed in these firms and the latter were found in a variety of manufacturing and commercial sectors rather than being limited to a single economic niche. Wilson and Portes’ (1980) analysis made three principal claims: 1) that the enclave was a distinct economic sector, separate from the "primary" and "secondary" sectors of the mainstream labor market; (2) that the economic payoff for human capital brought from the home country was higher in the enclave than in the sectors of the mainstream economy that employed immigrant labor; 3) that enclave entrepreneurs received higher economic returns than co-ethnics with comparable human capital, even when the latter were employed in the better sectors of the mainstream economy.

Wilson and Portes provided empirical evidence for their argument on the basis of data from a sample of Cuban exiles who arrived in the United States in the early 1970s and were followed throughout the decade. Discriminant analysis was used to demonstrate the existence of an enclave sector, different from the primary and secondary sectors of the mainstream labor market. Earnings regressions, within and across sectors, were then used to support the remaining hypotheses.

The enclave hypothesis garnered attention at the time because it ran contrary to conventional economic and sociological wisdom. The latter argued that ethnic economies were 
at best an employer of last resort with distinct disadvantages relative to entrance into mainstream sectors of the economy. At worst, they were characterized as "mobility traps" confining immigrant and ethnic minorities to a condition of permanent disadvantage (Borjas 1986, 1990; Bates 1987, 1989). The opposite tack was retaken by Portes and Bach (1985) in their comparative analysis of employment and income among Cuban and Mexican immigrant males in the late 1970s. Their results went beyond those reported earlier by focusing on determinants of enclave entrepreneurship. Using the same data set as Wilson and Portes, they found that the principal determinants of self-employment among Cubans in Miami were parental human capital, education, and most importantly having been employed in a co-ethnic firm at an earlier time (Portes and Bach 1985: 226-232).

The physical "look" of immigrant enclaves was described as follows:

Near downtown Los Angeles there is an area approximately a mile long where all commercial signs suddenly change from English to strange pictorial characters. Koreatown, as the area is known, contains the predictable number of ethnic restaurants and grocery shops; it also contains a number of banks, import-export houses, industries, and real estate offices. Signs of "English Spoken Here” assure visitors that their links with the outside world have not been totally severed...

A similar urban landscape is found near downtown Miami. Little Havana extends in a narrow strip for about five miles, eventually merging with the southwest suburbs of the city. Cuban firms are found in light and heavy manufacturing, construction, commerce, 
finance, and insurance. An estimated 60 percent of all residential construction in the metropolitan area is now done by these firms (Portes and Rumbaut 1996: 20-21).

\section{Testing the Enclave Hypothesis}

The interest produced by the notion that ethnic enclaves could be "mobility machines" rather than "traps" led to a number of studies that sought to test the idea or put it to use. Looking back in history, Portes and Bach had identified several similar communities constructed by immigrant groups at the beginning of the twentieth century. Two, in particular, deserved attention: the Jewish enclave in the Lower East Side of Manhattan and the Japanese enclave in Los Angeles. Both served as effective platforms for the economic incorporation of these immigrant groups leading, by the third generation, to levels of income and occupational status that exceeded those of the native white population (Portes and Bach 1985: 38-48).

Early attempts at applying the concept of ethnic entrepreneurial enclaves tended to yield positive results. Zhou (1992) for example applied the concept to her ethnographic study of New York's Chinatown finding that employment in this enclave had positive effects both for entrepreneurs, in the form of higher incomes and, for employees, in the form of opportunities for self-employment. While workers could initially receive low wages and worked longer hours, these disadvantages were compensated for by on-the-job training and social ties, facilitating their acquisition of their own business after some years. These advantages applied only to male workers, however, as women remained confined to the role of supporting the entrepreneurial initiatives of their husbands or other male kin (Zhou 1992; Zhou and Logan 1989). 
These gender differences in access and economic returns to self-employment were replicated in a subsequent study of the original Cuban enclave in Miami (Portes and Jensen 1989). On the basis of a different data set and drawing largely on the economic experiences of immigrant minorities in New York, Bailey and Waldinger (1991) defined the enclave labor market as a "training system" where the example and skills of successful entrepreneurs and ethnic bonds of solidarity facilitated the emergence of new firms which produced, in turn, new employment opportunities. In his studies of the needle trade and of various New York public bureaucracies, Waldinger $(1986,1996)$ showed how access to information made available through social networks led to the construction of "niches" dominated by members of a particular immigrant or ethnic group.

Taking a different tack, Logan, Alba, and McNulty (1994) sought to measure the range and depth of ethnic economies created by different immigrant groups on the basis of census data. For this purpose, they classified all private sector workers in each target metropolitan area into self-employed vs. employed by others, and by industry sector, recombining two-digit industry codes into 47 categories. "Enclave economies” included those sectors where both self-employed and employees from a particular ethnic or immigrant group were overrepresented. "Entrepreneurial niches” comprised those sectors where the self-employed, but not workers from a given group were over-represented.

On the basis of these criteria, Logan et. al. were able to "map" the ethnic economies of different groups in metropolitan areas nationwide. In agreement with earlier descriptions by Portes and Bach, they found that well-developed enclave economies were exceptional, being associated with only a few immigrant groups, such as the Korean and Chinese. None, however, came close to the original enclave in Miami in terms of number of sectors and strength of the 
immigrant presence in those sectors. Unlike most ethnic groups in other cities which were overrepresented in only a few sectors of the economy, the entrepreneurial and wage labor presence of Cubans in the Miami economy was widespread. These findings replicated those of Wilson and Martin (1982) a decade earlier who found not only great diversity in the internal composition of the Cuban enclave, but also dense networks among these firms so that the "outputs" of some were utilized as "inputs" for others. Such tight social and economic networks gave enclave firms a distinct advantage, allowing them to compete, despite their smaller size, with those in the mainstream economy.

Arrayed against these generally supportive findings, a number of studies emerged that questioned the benefits of ethnic entrepreneurship and even the very existence of entrepreneurial enclaves. Several economists have taken a dim view of ethnic entrepreneurship and selfemployment in general. Borjas (1990), for example, flatly asserts that, "There is no evidence that immigrant entrepreneurs are particularly successful. The presumption that many immigrant entrepreneurs begin with small shops and through their ability and hard work accumulate substantial wealth is a myth” (pp. 163-64). Similarly, Bates and Dunham (1991) dismiss the prevalence of self-employment among immigrant groups with the comment that "it may reflect in part the language difficulties that restrict employment alternatives” (p. 12). Bates (1993: A14) concludes that because of the "meager returns" to entrepreneurship only immigrants who are not fluent in English follow the entrepreneurial path.

These assertions were made despite consistent evidence that immigrant and native entrepreneurs receive higher earnings than their co-ethnic wage earners. Borjas, for example, sees as a myth that entrepreneurship helps immigrants despite his own evidence that selfemployed immigrants earn about 48 percent more than their waged counterparts. He discounted 
this difference because "the income advantage of self-employed over salaried workers disappears after controlling for the large differences in demographic characteristics between the two groups” (Borjas 1990: 164-65). Similarly, Bates (1989) and Bates and Dunham (1991) argue that the earnings advantage of immigrant entrepreneurs is a result of their greater human capital. Arguing that self-employment does not "pay" after rendering entrepreneurs and wage workers artificially equivalent is questionable. More telling is that immigrants with higher education and other skills commonly choose the entrepreneurial route as a way of making those skills pay off. That the better qualified often choose entrepreneurship runs contrary to assertions that this path is a mobility trap.

Portes and Zhou $(1996,1999)$ have further demonstrated that self-employment has significant net positive effects on absolute earnings among both native and immigrant groups, even after controlling for human capital and demographic characteristics. Borjas et. al. reached their conclusions by relying on the log linear functional form of the earnings equation. This function achieves a better fit to the assumption of normally distributed residuals, but only at the cost of obscuring substantively important information. Positive outliers (i.e. those with very high earnings) who are "pulled" toward the mean of the distribution by the log linear form are disproportionately entrepreneurs. Put differently, among individuals who have achieved extraordinary economic success, the self-employed are heavily represented. This is pertinent information to the question of whether this route to economic adaptation pays or not, but it disappears from view by the statistical choice of regressing only logged dollars.

Sociological critics of the enclave hypothesis have questioned less the positive effects of self-employment on earnings than the effect that enclave employment has for workers. Sanders and Nee (1987), who took issue with Wilson and Portes' (1980) positive view of enclave 
employment, recognized nevertheless that "self-employment in an enclave economy appears to be well rewarded for a set of human capital characteristics” (p. 763). In assessing these and other critics, it should be noted that the original formulation of the hypothesis never asserted that enclave employees would have higher earnings, on average, than their counterparts in the mainstream economy. Instead, the point was that enclaves were entrepreneurial incubators, showing wage workers the ropes to become self-employed themselves and that this shift, in turn, led to improved economic circumstances (Portes and Bach 1985; Bailey and Waldinger 1991).

A common problem in attempts to measure effects of enclave employment on economic outcomes is the difficulty of operationalizing the concept. Wilson and Portes (1980) and Portes and Bach (1985) defined the enclave as firms located in geographically circumscribed areas with high concentrations of other co-ethnic enterprises. Owners of these firms were defined as enclave entrepreneurs and workers in them as enclave workers. The original formulations of the hypothesis were grounded on survey data that unambiguously classified employed adults into these categories. In the absence of the necessary information in census data, investigators made use of various approximations of different degrees of plausibility.

As mentioned previously, Logan and his collaborators used overrepresentation in collapsed 2-digit census industrial categories to identify enclave sectors in specific metropolitan areas. While reasonable, this approach neglected the possibility that self-employed and wage workers in overrepresented sectors were not really part of the ethnic enclave and that those in underrepresented sectors were. There is considerable slippage in this approximation, making any conclusion about individual economic outcomes based on it rather tenuous (Logan et. al. 1994). More problematic still was the approach taken by Sanders and Nee (1987) who equated enclave participation with living in the area of entrepreneurial co-ethnic concentration. 
Residents in these areas may or may not work in enclave firms and the latter may employ or be owned by individuals who do not live in close proximity to them. Portes and Jensen (1989) demonstrated that enclave entrepreneurs generally do not live in areas where their firms are located, but in better-off suburbs. Conversely, areas of high ethnic business concentration tend to be inhabited by low-income workers, whether enclave employees or not. It is this residential difference that Nee and Sanders captured in their analysis, erroneously attributing them to the deleterious economic effects of enclave work.

Another attempt to test the hypothesis defined "enclave” as all Hispanic-owned businesses in New York City and went on to report that immigrant women working in these firms experienced lower wages and poorer economic conditions than those employed elsewhere (Gilbertson 1995). Obviously, there is no such thing as a "Hispanic" enclave in New York City since there is no immigrant nationality that goes by that name. There are concentrations of Dominican-owned firms in the Washington Heights area of upper Manhattan and of Colombianowned firms in Queens (Guarnizo 1994; Guarnizo et. al. 1999; Itzigsohn et. al. 1999) and these concentrations approach, in some dimensions, the characteristics of an enclave. However, this study did not focus on those areas, nor explained the dynamics of inter-ethnic relationships in them in a manner remotely resembling the fine-grained study of New York's Chinatown by Zhou (1992).

All that could be said on the basis of Gilbertson's findings is that firms that are the property of Latin immigrants or their descendants tend to pay lower wages to their female employees, a result that in no way bears on the predictions of the theory. A similar conclusion applies to Hum's (2000) attempt to test the enclave hypothesis on the basis of data from the Los Angeles Study of Urban Inequality (LASUI) (Bobo et. al. 2000). Hum correctly criticized prior 
attempts to operationalize the "ethnic economy" on the basis of place of residence or industrial sector. Instead, this author assigned workers to the "primary”, "secondary”, and "ethnic" labor market on the basis of job characteristics. "Ethnic economy" workers were those who had a coethnic supervisor and whose co-workers were mostly of the same ethnicity in firms no larger than 100 workers. Four nationalities were included: Chinese, Korean, Mexican, and Central American. On the basis of this operationalization, Hum conducted a series of multivariate analyses leading to the conclusion that “...mobility opportunities are limited in the ethnic economy. Contrary to its projection as facilitating the assimilation and mobility of new immigrants, the immigrant ethnic economy does not typically provide a meaningful alternative to exploitative dead-end work" (Hum 2000: 305).

Despite its use of a superior data set, this study exemplifies well the reigning confusion in this area. The study draws extensively from immigrant enclave theory and derives all its predictions from it. Then it proceeds to operationalize them, on the basis of a different concept, the "ethnic economy", which bears little relationship to the original definition of the enclave. Mexican workers laboring next to other Mexicans and with a Mexican supervisor may be part of an "ethnic economy", but they are certainly not part of an enclave. To be so, the firm had to be owned by Mexicans and located in an area of geographic concentration of such firms. The study provides no clue as to firm ownership or location. In the Los Angeles Metropolitan Area, there is no evidence that either Mexican or Central American immigrants have created enclaves making results about their respective economies irrelevant to the theory.

On the other hand, Koreans do possess a well-defined enclave in the area, as described by numerous past studies (Light and Bonacich 1988; Light and Gold 2000; Zhou 2004). Despite Hum's idiosyncratic measures, it is among this group where the "ethnic economy" does pay off. 
Thus, "the experience of Korean immigrants...emphasizes the centrality of self-employment and co-ethnic work relationship...Clearly, the quality of Korean ethnic economy employment stands out relative to the Chinese, Mexican, and Central American economies” (p. 305).

This conclusion is questionable, as well, with respect to the Chinese who also possess a well-defined enclave in suburban Monterrey Park (Fong 1994). Its location probably escaped the LASUI sample which also included a small number of Chinese workers $(\mathrm{N}=154)$. We have gone into such detail because this study represents the most recent and clearest example of the mischaracterization of the concept of ethnic enclave. The study draws its ideas and predictions from it, operationalizes them in ways bearing little relationship to the original definitions, and on the basis of predictable negative results concludes that the original hypotheses were wrong. The concept of enclave is quite distinct from that of "ethnic economy". According to authors working on the latter tradition (Light and Rosenstein 1995; Light and Gold 2000), all groups possess an ethnic economy of some sort. On the contrary, as the original theory and subsequent analyses have noted, enclaves are exceptional and have emerged only among a few immigrant minorities (Portes and Bach 1985; Portes and Jensen 1989; Zhou 2004).

\section{Revisiting the Cuban Enclave in Miami}

The enclave hypothesis was grounded on the remarkable economic experience of Cuban exiles in Miami in the 1960s and 1970s. Many escaped the communist revolution on the island with literally their "shirts on their backs"; few had property or capital in the United States; and practically none planned on permanent resettlement here, as they hoped for a prompt return to their country. The Bay of Pigs defeat of 1961 and the Missile Crisis episode the following year, where the Kennedy Administration traded the removal of Russian missiles from Cuba for a 
promise to rein exile efforts to overthrow the Castro regime, put an end to these hopes (Garcia 1996; Portes and Stepick 1993).

Highly concentrated in Miami for historical and geographical reasons, Cubans proceeded to rebuild lives and families there. Since many of the early exiles were entrepreneurs and professionals, they mobilized their skills, along with their networks to launch fledgling enterprises. Through devices such as the "character loans", which Cuban bank officers advanced to clients without collateral on the basis of their business reputation in the island, many exile firms got a start (Portes and Stepick 1993: 132-135). Initially, these firms located in areas of coethnic concentration in the "Little Havana" section of Miami and in the city of Hialeah, but eventually they expanded throughout the entire metropolitan area (Perez 1992; Stepick et. al. 2003).

Cuban-owned firms grew nationwide from an estimated 919 in 1967 to about 36,000 in 1982 and 61, 500 in 1987. Most of these were found in the Miami/Ft. Lauderdale metropolitan area. Aggregate receipts of Hispanic firms in Miami were \$3.8 billion in 1987, a figure that exceeded by $\$ 400$ million that of second-ranking Los Angeles and was three times that of New York despite these cities having much larger Hispanic populations (Portes and Stepick 1993: 146). By 2000, the rate of self-employment per thousand employed persons nationwide was 93.5, while for Cubans it reached 127.3 (U.S. Bureau of the Census 2000). By 2001, there were 125,273 Cuban-owned firms in the United States, with receipts of over 26.4 billion dollars. The majority of these concentrated in Miami/Ft. Lauderdale. There were 144 firms per 100,000 Cuban-origin population, a rate that quadrupled the figure among Mexicans, the largest Hispanic group, sextupled that among African-Americans, the largest domestic minority, and exceeded by 
a significant margin the rate among the native-born population as a whole (U.S. Bureau of the Census 2001).

The remarkable story of the Cuban economic and, subsequently, political rise in South Florida has been told many times and with very different hues before. The concept of the enclave, born out of this experience, was then applied to other immigrant entrepreneurial concentrations, such as Chinatown in New York, Koreatown in Los Angeles, and Little Saigon in Orange County (Zhou 1992; Zhou 2004; Rumbaut 1990, 1994); as well as large working-class immigrant communities such as Mexicans in the Pilsen area of Chicago (Raijman and Tienda 1999). As seen in the prior section, numerous attempts to test this hypothesis stretched the original definition of enclave beyond recognition. It seems, therefore, appropriate to return to Miami to see what happened to the group that created the phenomenon in the first place and to its descendants. If the hypothesis that concentrated entrepreneurship provides a viable form of economic adaptation for immigrant and ethnic minorities holds, it is among Cubans in Miami where these outcomes should be most prominent and visible.

Alternatively, if ethnic entrepreneurship and ethnic business concentrations are "mobility traps” (Bates 1989), then the economic profile of a group that decisively opted for this route should show these results most clearly. The 5 percent micro-data sample (IPUMS) from the 2000 Census provides appropriate data to put these competing ideas to a test. Not only does the sample contain a sufficient number of cases and information on all relevant variables, but it comes from a census taken two decades after the original hypothesis was formulated. This allows us to examine the long-term evolution of this immigrant community and the results of its chosen path of economic adaptation. 
Credible attempts to apply the concept of enclave to other immigrant/ethnic groups have always been grounded on historical knowledge and direct observations of the dynamic of these communities (Guarnizo 1994; Zhou 1992; Raijman and Tienda 1999). On the contrary, misapplications of the concept and faulty conclusions have generally been based on secondary analyses of census or survey data without any close familiarity with the groups studied, their histories, and modes of incorporation. For this reason, an analysis of 2000 Census data for Cubans in Miami must take into account the evolution of this community in the interim period, that is from 1980 to 2000 .

The defining event for Cubans during this period was the Mariel exodus of 1980. The decision of the Cuban government to open the port of Mariel to all exiles wishing to take their relatives out of the island triggered a massive and chaotic new wave that brought to South Florida 125,000 refugees in less than six months. The Cuban government took advantage of the episode to empty its jails and mental hospitals, putting the inmates aboard the boats. The spectacle of a chaotic flotilla and of boats of ragged people arriving in the Florida keys everyday triggered a strong negative reaction in the United States. The Carter Administration refused to grant the new arrivals refugee status, categorizing them as "entrants, status pending”. The public reaction to the Mariel episode shifted the perception of Cubans from a "model minority" and "the builders of the new Miami" to one of the most unpopular foreign minorities in the nation. Aware of this shift, the older exile community distanced itself from the new arrivals, coining the derogatory term marielitos to refer to them (Portes and Stepick 1993; Perez 1992; CamaydFreixas 1988).

Mariel marked a pivotal shift in modes of incorporation for Cubans arriving in U.S. shores. Prior to 1980, exiles, which included almost the entire pre-revolutionary elite, had been 
warmly received by the federal government, were eligible for extensive resettlement assistance, and were perceived by the general public as a deserving group, loyal U.S. allies in the global struggle against communism. During Mariel and after, all of this changed. Cubans became just another Third World impoverished minority seeking to crash the doors of the nation; the federal government focused its efforts on stopping the inflow and treated new arrivals with much less benevolence than their predecessors. Following an accord with the Cuban government in 1994, all new refugees caught by the U.S. Coast Guard at sea were promptly returned to Cuba (Stepick et. al. 2003; Perez 2001).

More important still, the old middle-class Cuban population of Miami largely severed their ties with the new arrivals. They were not part of old Cuba, having been raised during the revolutionary period, and lacked strong kinship and friendship ties with the established Miami Cuban community. Perceiving the marielitos and post-Mariel entrants as responsible for the rapid decline of Cubans’ public image in the United States and having few social links with them, pre-1980 exiles came to regard the newcomers as a group different from themselves. The separation was physical, as well as social - the old middle-class Cuban population settled in the comfortable suburbs of Coral Gables and Kendall; Mariel and post-Mariel refugees crowded in the poor city of Hialeah and the deteriorating "Little Havana” quarter of Miami (Portes and Stepick 1993; Garcia 1996).

This rupture in modes of incorporation means that Mariel and post-Mariel refugees benefited little from the pre-1980 enclave and its internal ties of solidarity and mutual business support. No "character loans" were available to prospective new entrepreneurs for they were not known to Cuban bank officials. No tips about new business opportunities were available to them. While many eventually went to work for Cuban-owned firms in Miami, and some 
eventually learned the ropes of self-employment, their links to business owners and to the established Cuban community at large were much weaker (Portes and Jensen 1989; Stepick et. al. 2003). These differences in the internal composition and evolution of the Cuban community must be taken into account when analyzing its economic performance by the end of the twentieth century.

\section{Results}

\section{a. Preliminary Findings}

The IPUMS files provide data for 66,955 adults, ages $18-65$ who earned more than $\$ 500$ in the Miami/Ft. Lauderdale MSA. This large sample can be divided into ethnic categories of Non-Hispanic White, Non-Hispanic Black, Cuban, Other Hispanic, and Other. The last category is composed mainly of first- and second-generation Asians. The Cuban-origin sample is composed of 12,004 that can be further subdivided into Pre-1980 (pre-Mariel) arrivals, Mariel (1980) and later arrivals, and the U.S.-born second generation. Table 1 presents personal and family incomes for these ethnic categories.

Results show that non-Hispanic whites $(\mathrm{N}=25,387)$ occupy the top of the economic hierarchy with incomes higher than any other group. All other groups have average personal incomes that are significantly lower but, of these, only pre-1980 Cuban arrivals and the U.S.born Cuban second generation have incomes that exceed the mean for the metropolitan area. In particular, only pre-1980 Cubans significantly exceed $\$ 40,000$ in average personal income, approaching the non-Hispanic White figure. The trend is the same when we consider family incomes. In this case, only non-Hispanic whites and pre-Mariel Cubans exceed \$80,000 in annual income, with the Cuban second generation shy of that amount by a little more than 
$\$ 1,000$. The second generation is a group composed, almost exclusively, of persons born before 1980 (age 20 or higher in 2000) and, hence, the offspring of pre-Mariel Cubans. By contrast refugees arriving during the Mariel exodus and after have not succeeded economically. Their personal and family incomes are even lower than other Hispanic immigrants in the area and are not statistically different from Non-Hispanic Blacks, the bottom ethnic category.

Tables 1a and 1b about here

Table 2 disaggregates these figures further into the categories of self-employed and wage earners among adult males (there are not sufficient numbers of self-employed females to permit inter-ethnic comparisons). Self-employed Cubans in Miami are, almost by definition, ethnic enclave entrepreneurs since, as explained previously the original business networks of the enclave grew out of the city of Miami to encompass the entire metropolitan area. This is especially the case among pre-1980 exiles - founders of the original enclave and their offspring. By contrast, Cuban waged and salaried workers may or may not be employees of the enclave economy. While the data provide no means to establish this comparison, they allow us at least to examine the economic situation of Cuban workers who arrived at the time the business enclave was being built and those who came during the Mariel exodus and later.

The same ethnic hierarchy observed earlier holds, with Non-Hispanic Whites at the top, pre-Mariel Cubans close behind, followed by their children and everyone else below. As repeatedly noted in prior studies, entrepreneurs (the self-employed) enjoy a substantial economic advantage in terms of personal and, especially, family incomes. Non-Hispanic Whites and pre1980 Cuban entrepreneurs are the only groups to exceed an annual family income of $\$ 100,000$, 
with the difference between the two groups just shy of $\$ 1,000$. They are followed, at some distance, by second generation Cubans, and then all others. Differences among waged and salaried workers follow exactly the same pattern: There is no statistical difference between the average incomes of Non-Hispanic White and Pre-Mariel Cuban workers, while all other groups fall significantly behind. This result indicates that those Cuban workers who arrived at the time that the ethnic enclave developed have done rather well economically, whether they are employed by these firms or not.

Tables 2a and 2b about here

The difference is stark with the economic performance of Mariel and post-Mariel refugees whose income levels are at the bottom of the ladder for both the self-employed and the employees and in personal as well as family incomes. Noteworthy in particular is the dismal performance of entrepreneurs from this group whose economic rewards are the lowest of all ethnic categories, being surpassed by other Hispanics and African-Americans. It is evident from these results that the original advantages conferred on would-be entrepreneurs by networks within the Cuban enclave did not extend to the later arrivals. They are, as it were, a group apart. Part of this disadvantage may be due to their recency of arrival, a possibility that will be examined in the next section. However, second generation Cubans entered the local labor force at about the same time, i.e., they were also "recent” workers with little work experience. Yet, their economic achievements as both new entrepreneurs and workers far exceed those of their Mariel compatriots. 
This is not because of lack of trying among recent arrivals. Table 3 presents selfemployment rates for all adult males in the Miami metropolitan area by ethnic categories in 2000. Two trends are apparent in these results: First, pre-Mariel Cubans are the most entrepreneurial group, with a rate significantly higher than non-Hispanic whites. This result accords with the historical role of this group as builders of the enclave economy. Second, Mariel and post-Mariel Cubans have also been strongly inclined to follow that route with selfemployment rates not significantly lower than non-Hispanic whites. However, as just seen, their efforts have not paid off so far. This outcome is largely attributable to their exclusion from the resources in credit, business information, and opportunities that flowed from the original networks of the enclave.

Table 3 about here

Despite these disadvantages, the existence of the Cuban enclave seems to have benefited workers of the same nationality, regardless of the time of arrival. In one of the original formulations of the theory, Portes and Bach (1985) argued that the existence of a dense network of co-ethnic enterprises allow recent arrivals to put to use the human capital brought from the home country, even without knowledge of English. While in the mainstream economy, lack of English condemns immigrant workers to the most menial occupations, this is not true in enclave enterprises where the language of work is frequently that of the home country.

Table 4 presents the incomes of immigrant waged and salaried workers in the Miami/Ft. Lauderdale MSA who did not speak English well at the time of the 2000 Census. The four subtables present data on personal and family incomes, for the male and total populations. In all 
cases, results indicate that Cuban workers receive incomes significantly higher than other immigrants in the same situation. Since the data also indicate that immigrants without English do not differ significantly across nationalities in other dimensions of human capital, the results suggest that Cubans were better able to put to use whatever human capital they brought from their country. This result is in agreement with the original hypothesis. The existence of the Cuban enclave has given new arrivals and older workers without much education (who are those who most commonly do not know English) economic opportunities absent in the mainstream economy. Immigrants from other nationalities have not been so fortunate.

Table 4 about here

Finally, the general pattern of results observed in the Census data repeats itself in other recent surveys conducted in the area. Table 5 presents findings from a large survey of immigrant parents, conducted in 1996 in conjunction with the first follow-up wave of the Children of Immigrants Longitudinal Study (CILS) in South Florida. The original sample of second generation $8^{\text {th }}$ and $9^{\text {th }}$ graders was representative of the relevant population in the schools of the Miami/Ft. Lauderdale metropolitan area. The parental survey included a random sample of 50 percent of the original respondents, making it, in turn, representative of that universe. As seen in Table 5, Cuban parents had significantly higher family incomes on average than those of all other nationalities combined. In turn, enclave entrepreneurs in this sample (self-employed Cuban parents) had the highest annual earnings of any category, exceeding co-ethnic employees by almost $\$ 20,000$ and other immigrant parents by over $\$ 25,000$. 
Table 5 about here

\section{Multivariate Analysis: Income Determinants}

The average inter-ethnic differences observed previously are suggestive, but are subject to the objection that they reflect differences in levels of human capital, including education and work experience. As seen previously, some economists make much of the fact that entrepreneurs tend to have higher levels of human capital, using this fact to conclude that the economic gain from self-employment is a "myth”. More reasonably, it could be argued that pre-Mariel Cubans represent an older and, hence, more experienced population and that this is the root cause of their superior economic performance.

In the following multivariate analysis, we use actual dollars throughout for reasons explained in detail in Portes and Zhou (1996). The log linear form of income regressions expresses the proportional net gain or loss associated with a unit change of each predictor, relative to the average of the distribution. As Hodson (1985: 387) has noted, the proportional net effects produced by the log linear form can obscure real differences between categories of individuals in a comparative analysis. This occurs because the log linear form's relative effects are a partial function of each category’s mean income. ${ }^{1}$ Further, the log linear form achieves a better approximation to normality by neutralizing the influence of income outliers. For the purpose at hand, this means suppressing valuable information since entrepreneurs are

\footnotetext{
${ }^{1}$ For example, a low absolute rate of return per year of education for women may yield a high proportional rate because the log linear coefficient reflects an effect relative to the mean earnings of women, which tend to be much lower than men's.
} 
disproportionately represented among positive income outliers, this result being indicative of their economic success.

For reasons of space, we restrict the presentation of results to family income which provides a more accurate measure of overall family economic well-being. We conducted a parallel analysis of personal incomes and its results tend to reproduce, in all essential aspects, those to be discussed next. Table 6 presents regressions of family incomes in actual dollars for the adult working population of Miami/Ft. Lauderdale on indicators of human capital, selfemployment, and ethnic origins. The first model presents the effects of all main ethnic categories, while the second disaggregates the Cuban-origin population into the sub-categories discussed previously.

Table 6 about here

Three main findings emerge from this analysis. First, education and work experience, indexed by age, have the expected strong net effects on incomes, as does gender. College and post-college graduates derive an advantage to their education measured in the tens of thousands of dollars relative to high school dropouts (the reference category). Women suffer the welldemonstrated income handicap relative to statistically equivalent males. Second, after controlling for these predictors, self-employment continues to have a positive and significant effect. Compared to workers of the same education, work experience, gender, and ethnicity, the self-employed have a net annual income advantage of $\$ 14,000$ in this sample.

Third, all ethnic categories earn significantly less than Non-Hispanic whites, even after controlling for human capital, gender, and self-employment. These differences are statistically 
significant in the first model, but disappear when the Cuban-origin sample is disaggregated. PreMariel Cubans and the U.S.-born Cuban second generation now exhibit incomes that are higher than comparable Non-Hispanic whites, although the differences are not statistically significant. In contrast, Mariel and post-Mariel Cubans continue to experience an income disadvantage that is higher than that suffered by any other ethnic category, including African-Americans. The annual income gap relative to statistically comparable native whites is a startling $\$ 23,000$ for this segment of the Cuban population.

With human capital indicators and gender controlled, the differences show clearly the advantages of entrepreneurship in general and of involvement in the enclave economy, in particular. It is the cohort associated with its creation in the 1960s and 1970s and its descendants that have been most able to reap its benefits, matching or exceeding the economic performance of native whites. Mariel and post-Mariel Cubans have been largely excluded from the resources of the enclave, and, in consequence, have been relegated to the economic level of other disadvantaged racial and ethnic minorities.

A possible objection to these findings is that age is not a good indicator of U.S. work experience. Mariel and post-Mariel entrants of the same age as pre-1980 Cubans may have much fewer years of experience in the American labor market because of their recency of arrival. In order to take into account this possibility, we substituted U.S. work experience for age across all ethnic groups. For the native-born, work experience is computed in standard fashion as age minus education minus six. For adult immigrants, it is years since U.S. arrival minus $y$, where $y$ is 0 for those who arrived after age 18 and (18 - age at arrival) for those who arrived as minors. Table 7 presents the result for the adult universe and for males only. 
Table 7 about here

With work experience brought into the equation, results are still more powerful than before. The Cuban second generation remains statistically indistinguishable from Non-Hispanic Whites, although they receive slightly lower average incomes. On the other hand, pre-Mariel Cubans males now exceed the incomes of the reference category by a significant margin. Net of work experience and other control variables, this group of earlier exiles displays a net income advantage over native white males of almost $\$ 4,000$.

A second pertinent question is whether income determinants differ among ethnic groups and, in particular, whether the overall positive effect of self-employment on annual incomes vary significantly among them. The enclave hypothesis predicts that it does and that the effect is more marked among the more entrepreneurially-inclined groups, especially among those in dense co-ethnic concentrations (Wilson and Martin 1982; Zhou 2004). Entrepreneurship should "pay” more in this situation because of access to otherwise unavailable or more expensive resources, such as in-site business apprenticeship, subsidized credit, captive markets, and disciplined labor (Raijman and Tienda 1999; Bailey and Waldinger 1991). Table 8 presents relevant results for the total adult working population of Miami/Ft. Lauderdale with Cubans as a single ethnic category. Significant differences from Non-Hispanic whites are indicated by the number sign (\#). 
Table 8 about here

There are indeed numerous differences among all ethnic groups relative to native whites, indicating that the income attainment process varies significantly between them. There are several suggestive results in these models, such as the linear effect of work experience - stronger for Cubans than for any other group - and the net effect of gender (female) which turns positive among Other Hispanics and Others (Mostly Asians), after controlling for other predictors. The key results of interest are the coefficients associated with self-employment, which again vary widely across groups. The net effect is always positive, but it is too small to be significant among African-Americans. In agreement with the enclave hypothesis, the effect is strongest among the three most entrepreneurial groups - Non-Hispanic Whites, Others (Asians), and Cubans - and there are no statistically significant differences among them. Cubans, however, derive a smaller absolute benefit from entrepreneurship, a result which runs contrary to expectations since they are the only group associated with a full-fledged enclave in the area. Results limited to adult males (not shown) reproduce this pattern.

Results in Table 9 clarify this anomaly: Pre-Mariel Cubans receive the highest payoff for entrepreneurship of any group, exceeding by over $\$ 6,000$ the comparable figure among NonHispanic whites. In agreement with prior results, the gain associated with self-employment for Mariel and post-Mariel Cubans, while still significant, is less than one-fourth the figure among their pre-1980 compatriots. A final result of note is that the net effect of self-employment is statistically insignificant among the Cuban second generation. This indicates that economic advantages observed previously for this group do not depend on its being highly entrepreneurial. 
Offspring of successful immigrant businessmen do not necessarily follow in the footsteps of their parents. They may use instead resources accumulated by the first generation for an advanced education and for entry into well-paying professional careers.

This pattern accords with the experience of earlier immigrant enclaves chronicled in the literature, such as those created by Russian Jews on the Lower East Side of Manhattan and by the Japanese in Los Angeles and San Francisco (Howe 1976; Rischin 1962; Petersen 1971). As in these earlier formations, enclaves do not seem to be self-perpetuating phenomena, but "platforms" for successful entry into the social and economic mainstream by the children and grandchildren of the original entrepreneurs (Portes and Bach 1985).

Table 9 about here

Multivariate Results: Determinants of Self-Employment

Given the consistent positive economic effect of entrepreneurship for the entire sample and for most ethnic groups, it is worthwhile to examine what leads to entry into this economic route. For this purpose, we modeled the probability of entrepreneurship (self-employment $=1$ ) on the same set of regressors used previously in a series of logistic regressions. We examine first the main effects of ethnicity on self-employment and then the interaction effects across the various groups. Table 10 presents results in the form of net odd-ratios taken to the fourth significant digit. The table shows that the principal determinant of entrepreneurship is an advanced education. The odds of persons with a post-graduate degree becoming self-employed are 1.36-to-1.00, relative to those with less than a high-school education. The effect of education 
on entrepreneurship is non-monotonic since those with a high school degree or college are less likely to be self-employed than high school dropouts. This suggests a bi-modal pattern in which entrepreneurship is embraced by the most educated as a vehicle for economic advancement and by those with the least education as a possible vehicle for survival. We will examine whether this pattern is reproduced among all ethnic groups or whether it is exclusive to some of them. In agreement with past results in the literature, females are significantly less likely to be selfemployed.

Table 10 about here

The ethnic coefficients reveal an interesting pattern of results: Relative to Non-Hispanic whites, all groups, except Cubans, are significantly less likely to be self-employed. The odds among African-Americans are particularly miniscule, 0.37-to-1.00. This pattern indicates that the group normally ranked at the top of the ethnic hierarchy, native whites, not only derives significant economic benefits from independent enterprise (see Table 8), but also chooses this route far more frequently than others, especially the most downtrodden ethnic minorities. The only exception in Miami/Ft. Lauderdale are Cubans who, controlling for human capital and gender differences, are significantly more likely to become entrepreneurs than Non-Hispanic Whites. This result again supports prior results highlighting the impact of the emergence of the enclave economy in this area.

The second panel of Table 10 disaggregates the Cuban population showing results that would, by now, be unsurprising. The real high level of entrepreneurship is found among preMariel Cubans whose odds of doing so, controlling for human capital and gender, are 1.29-to- 
1.00, relative to native whites. Later arrivals are not significantly different from the reference category in pursuing the entrepreneurial route - a result indicating that a significant number do, albeit with poorer economic results as shown previously. The U.S.-born Cuban second generation is significantly less likely to be self-employed. This finding confirms prior ones to the effect that this group neither derives major income benefits from entrepreneurship, nor is it likely to follow that route. Its economic prowess comes from elsewhere, namely using the resources of the enclave to pursue highly-paid professional careers. The well-documented rapid ascent of the Jewish second generation out of the Lower East Side and into the professional ranks in New York City during the mid-twentieth century (Rischin 1962; Goldschneider 1986) is closely mirrored in this Miami pattern by the end of the century.

Inter-ethnic differences on determinants of self-employment are presented in Table 11. The principal story here is the contrasting effects of educational achievement on employment for native whites and Asians (grouped in the "Other" category), on the one hand, and Cubans, on the other. For the first two groups, any level of education above high school has a positive effect on self-employment, although only a post-college education yields a significant effect for both groups. For Cubans, on the other hand, all educational levels below an advanced post-graduate education have negative effects. This is as true of pre-Mariel Cubans as of later arrivals and the second generation.

Since educational coefficients are computed relative to high school dropouts, this pattern of results suggests dual entry routes into entrepreneurship. It also indicates that the previously observed finding of higher rates of self-employment among high school dropouts is due entirely to the economic behavior of Cubans in this area. Both the highly educated (best represented among the earlier exiles) and the least educated (better represented among the post-1979 cohorts) 
took the entrepreneurial route in significantly higher numbers than the rest of their co-ethnics and other ethnic groups in the city. For those at the top, it has represented a vehicle for rapid economic advancement. For those at the bottom, it has been primarily a vehicle for survival since, as seen previously, the group most clearly associated with this form of self-employment did not derive a significant economic payoff from it. The story suggested by these results is that educationally-disadvantaged refugees, common among the later Cuban waves, did try to emulate the business prowess of established enclave entrepreneurs, but without the same results. This reflects again the social and economic bifurcation of the Miami Cuban community, as described previously.

Table 11 about here

\section{Conclusion}

The development of theoretical concepts - what Weber ([1904] 1949) called “ideal types” - represents the culmination of successful long-term inquiry into any area of social or historical reality. Concepts are valuable heuristic tools that highlight certain features of the social world and summarize, in a word or phrase, what is known about them. By the same token, concepts stimulate further investigation through the explanations and predictions (hypotheses) that they generate. However, once formulated, concepts have the character of a "public good", freely available to everyone. This availability is, in principle, a good thing, but it runs the risk of misrepresentation or overuse of the original idea. In their quest to make their mark on the scientific world, investigators may stretch the intended meaning of the concept, all the while 
claiming that they are putting it to rigorous empirical test. The more a concept gains visibility and popularity among the lay or scientific publics, the more it is prone to this pattern of distortion (Merton 1968: Ch. 1).

Something of the sort took place after the formulation of the concept of ethnic enclave a quarter of a century ago. As seen in the introductory sections, attempts at testing its implications have been frequently marred by faulty operationalizations or by outright misinterpretations of the theory. While it is true that finding appropriate measures of what an enclave is and of who is or is not an enclave entrepreneur is difficult, there is also a willful resolve - most common among some economists - to demonstrate that the independent business route does not pay for minorities and, hence, that the possibility of successful ethnic entrepreneurship is a "myth".

In this context, a retrospective glance at the concept of enclave and at the immigrant group most closely associated with its formulation seems worthwhile. The two resources needed to accomplish this are fortunately at hand: a) recent census data on the economic performance of different ethnic groups in the relevant metropolitan area; and b) knowledge of the history of the target immigrant nationality in the two intervening decades. Without this kind of knowledge, the analysis and interpretation of census figures would become meaningless, a lesson that extends to the investigation of similar ethnic formations elsewhere.

Results of this analytic exercise correspond fairly well to the original theoretical expectations in several ways: the total and net economic payoffs to entrepreneurship; the prevalence of this form of economic adaptation among certain groups, but not others; and the determinants of entry into it within and between these groups. A 20-year retrospective offers an authoritative standpoint to assess the economic situation and performance of any immigrant minority. From this perspective, we have seen that the economic trajectory of Cuban exiles in 
Miami has been enviable, placing them at par, if not higher in some respects, than the white native segment of the population. This overall characterization offers, in our view, the best validation of the original concept as it is clear that this group could not have moved ahead without a rapid process of firm creation, backed by dense business networks. The pursuit of this route placed the earlier cohorts of Cuban exiles and their offspring at the top of an economically dynamic city. No other immigrant or ethnic group in it, except native whites themselves, have approached this situation.

A hypothetical parallel analysis of the same Census data that ignored the historical development of the Miami Cuban community would have completely distorted the facts by aggregating all members of this population into a single ethnic category. The emerging results would have been quite different and would have largely negated expectations stemming from the enclave hypothesis. As we have seen, the actual story has been different: benefits of enclave entrepreneurship accrued primarily to its original builders and, secondarily, to their offspring. The latter did not follow in their parents' footsteps but used their accumulated resources to obtain advanced degrees and enter well-paid careers. Later Cuban arrivals also followed the entrepreneurial route, but they were hampered in their efforts by the rupture of networks (and hence the opportunities and resources that they provided) with the older exile community.

Throughout this period, the only other group that paralleled pre-Mariel Cubans in rates of entrepreneurship and in the benefits derived from it were native whites themselves. This should put to rest some economists' stories that the only "real” route to economic mobility is through salaried employment. When the group at the top of the ethnic hierarchy eagerly pursues entrepreneurship as an alternative to salaried work, we can be certain that its returns are anything but a "myth". For the Cubans, as for other immigrant groups such as the Chinese and the 
Koreans, as well as for the Russian Jews and the Japanese in the early twentieth century, the building of a business enclave was the key tool that allowed them to carve a socially respectable and economically viable place in the midst of American society. Absent this tool, their fate in a highly competitive and racially stratified economy would have been quite different. 


\section{References}

Bailey, Thomas and Roger Waldinger. 1991. "Primary, Secondary, and Enclave Labor Markets:

A Training System Approach." American Sociological Review 56:432-45.

Bates, Timothy. 1987. "Self-Employed Minorities: Traits and Trends." Social Science Quarterly 68:539-51.

Bates, Timothy. 1989. "The Changing Nature of Minority Business: A Comparative Analysis of Asian, Non-Minority, and Black-Owned Business." The Review of Black Political Economy 18:25-42.

Bates, Timothy. 1993. “Helping Black Entrepreneurs.” Wall Street Journal, December 13, p. A14.

Bates, Timothy and Constance Dunham. 1991. "The Changing Nature of Business Ownership at a Route to Upward Mobility of Minorities." Presented at the Conference on Urban Labor Markets and Labor Mobility, Sponsored by the Urban Institute, March 7-8, Arlie House, VA.

Bobo, Larry D., Melvin H. Oliver, James H. Johnson, and Abel Valenzuela. 2000. Prismatic Metropolis: Inequality in Los Angeles. New York: Russell Sage Foundation.

Borjas, George J. 1986. "The Self-Employment Experience of Immigrants." The Journal of Human Resources 21:485-506.

Borjas, George J. 1990. Friends or Strangers, the Impact of Immigrants on the U. S. Economy. New York: Basic Books.

Camayd-Freixas, Yohel. 1988. Crisis in Miami: Community Context and Institutional Response in the Adaptation of Mariel Cubans and Undocumented Haitian Entrants in South Florida. Commissioned report. Boston Urban Research and Development. 
Fong, Timothy P. 1994. The First Suburban Chinatown: The Remaking of Monterey Park, California. Philadelphia: Temple University Press.

García, María Cristina. 1996. Havana USA: Cuban Exiles and Cuban Americans in South Florida, 1959-1994. Berkeley, CA: University of California Press.

Gilbertson, Greta A. 1995. “Women’s Labor and Enclave Employment: The Case of Colombian and Dominican Women in New York City.” International Migration Review 29: $657-70$.

Goldscheider, Calvin. 1986. Jewish Continuity and Change: Emerging Patterns in America. Bloomington, IN: Indiana University Press.

Guarnizo, Luis E. 1994. "Los 'Dominican Yorkers': The Making of a Binational Society." Annals of the American Academy of Political and Social Science 533:70-86.

Guarnizo, Luis E., Arturo I. Sanchez, and Elizabeth Roach. 1999. "Mistrust, Fragmented Solidarity, and Transnational Migration: Colombians in New York and Los Angeles." Ethnic and Racial Studies 22 (March):367-96.

Hodson, Randy. 1985. "Some Considerations Concerning the Functional Form of Earnings." Social Science Research 14:374-94.

Howe, Irving. 1976. World of Our Fathers. New York: Harcort, Brace, and Jovanovich. Hum, Terry. 2000. “A Protected Niche? Immigrant Ethnic Economies and Labor Market Segmentation.” Pp. 279-314 in Prismatic Metropolis: Inequality in Los Angeles, edited by L. D. Bobo, M. H. Oliver, J. H. Johnson, and A. Valenzuela. New York: Russell Sage Foundation. 
Itzigsohn, Jose, Carlos Dore, Esther Fernandez and Obed Vazquez. 1999. "Mapping Dominican Transnationalism: Narrow and Broad Transnational Practices." Ethnic and Racial Studies 22 (March): 316-339.

Light, Ivan and Edna Bonacich. 1988. Immigrant Entrepreneurs: Koreans in Los Angeles 19651982. Berkeley: University of California Press.

Light, Ivan and Steven J. Gold. 2000. Ethnic Economies. San Diego, CA: Academic Press. Light, Ivan and Carolyn Rosenstein. 1995. "Expanding the Interaction Theory of Entrepreneurship." Pp. 166-212 in The Economic Sociology of Immigration, edited by A. Portes. New York: Russell Sage.

Logan, John R., Richard D. Alba, and Thomas L. McNulty. 1994. "Ethnic Economies in Metropolitan Regions: Miami and Beyond." Social Forces 72:691-724.

Merton, Robert K. 1968. Social Theory and Social Structure. Enlarged edition. New York: Free Press.

Perez, Lisandro. 1992. "Cuban Miami." Pp. 83-108 in Miami Now, edited by Guillermo J. Grenier and Alex Stepick. Gainesville, FL: University Press of Florida.

Perez, Lisandro. 2001. “Growing up Cuban in Miami: Immigration, the Enclave, and New Generations.” Pp. 91-125 in Ethnicities: Children of Immigrants in America, edited by R. G. Rumbaut and A. Portes. Berkeley, CA: University of California Press and Russell Sage Foundation.

Petersen, William. 1971. Japanese Americans: Oppression and Success. New York: Random House.

Portes, Alejandro, and Robert L. Bach. 1985. Latin Journey: Cuban and Mexican Immigrants in the United States. Berkeley, CA: University of California Press. 
Portes, Alejandro, and Leif Jensen. 1989. "The Enclave and the Entrants: Patterns of Ethnic Enterprise in Miami Before and After Mariel." American Sociological Review 54:929-49.

Portes, Alejandro, and Ruben G. Rumbaut. 2001. Legacies: The Story of the Immigrant Second Generation. Berkeley, CA: University of California Press and Russell Sage Foundation.

Portes, Alejandro and Alex Stepick. 1993. City on the Edge: The Transformation of Miami. Berkeley: University of California Press.

Portes, Alejandro, and Min Zhou. 1996. "Self-Employment and the Earnings of Immigrants." American Sociological Review 61:219-30.

Portes, Alejandro, and Min Zhou. 1999. "Entrepreneurship and Economic Progress in the 1990s: A Comparative Analysis of Immigrants and African Americans." Pp. 143-71 in Immigration and Ethnicity in the United States, edited by F. Bean and S. Bell-Rose. New York: Russell Sage.

Raijman, Rebecca and Marta Tienda. 1999. "Immigrants' Socio-Economic Progress Post-1965: Forging Mobility or Survival?" Pp. 239-56 in The Handbook of International Migration, edited by P. K. C. Hirschman, and J. DeWind. New York: Russell Sage Foundation.

Rischin, Moses. 1962. The Promised City: New York Jews 1870-1914. Cambridge, MA: Harvard University Press.

Rumbaut, Rubén G. 1990. “The Structure of Refuge: Southeast Asian Refugees in the United States, 1975-1985.” International Review of Comparative Social Research 1:95-127.

Rumbaut, Rubén G. 1994. “Origins and Destinies: Immigration to the United States since World War II.” Sociological Forum 9:583-621.

Sanders, Jimy and Victor Nee. 1987. "Limits of Ethnic Solidarity in the Enclave Economy." American Sociological Review 52:745-73. 
Stepick, Alex, Guillermo Grenier, Max Castro, and Marvin Dunn. 2003. This Land Is Our Land: Immigrants and Power in Miami. Berkeley: University of California Press. U.S. Bureau of the Census. 2000. Five Percent Public Use Microdata Sample.

U.S. Bureau of the Census. 2002. Survey of Business Owners - Hispanic-Owned Firms. Washington, DC: U.S. Department of Commerce.

Weber, Max. [1904]1949. The Methodology of the Social Sciences. Translated by E. A. Shils and H. A. Finch. New York: The Free Press.

Wilson, Kenneth and W. Allen Martin. 1982. "Ethnic Enclaves: A Comparison of the Cuban and Black Economies in Miami." American Journal of Sociology 88:135-60.

Wilson, Kenneth and Alejandro Portes. 1980. "Immigrant Enclaves: An Analysis of the Labor Market Experiences of Cubans in Miami.” American Journal of Sociology 86(September): 295-319.

Zhou, Min. 1992. New York's Chinatown: The Socioeconomic Potential of an Urban Enclave. Philadelphia: Temple University Press. . 2004. “Revisiting Ethnic Entrepreneurship: Convergencies, Controversies, and Conceptual Advancements.” International Migration Review 38 (Fall): 1040-1074. Zhou, Min and John Logan. 1989. "Returns on Human Capital in Ethnic Enclaves: New York City’s Chinatown.” American Sociological Review 54 (October): 809-820. 
Table 1a

Personal Incomes of Racial and Ethnic Groups in Miami/Ft. Lauderdale Metropolitan Area (Adults 18-65)

\begin{tabular}{|c|c|c|c|c|c|c|c|c|}
\hline \multirow[b]{2}{*}{$\begin{array}{c}\text { Racial/Ethnic } \\
\text { Group }\end{array}$} & \multirow[b]{2}{*}{ Total MSA } & \multirow[b]{2}{*}{$\begin{array}{l}\text { Non-Hispanic } \\
\text { White }\end{array}$} & \multirow[b]{2}{*}{$\begin{array}{c}\text { Non-Hispanic } \\
\text { Black }^{1}\end{array}$} & \multicolumn{3}{|c|}{ Cuban } & \multirow[b]{2}{*}{$\begin{array}{c}\text { Other } \\
\text { Hispanic }\end{array}$} & \multirow[b]{2}{*}{ Other } \\
\hline & & & & $\begin{array}{c}\text { Pre-1980 } \\
\text { Migrant }\end{array}$ & $\begin{array}{c}1980 \text { or } \\
\text { After } \\
\text { Migrant }\end{array}$ & U.S. Born & & \\
\hline $\begin{array}{l}\text { Personal } \\
\text { Income }\end{array}$ & $\begin{array}{r}37,407 \\
(47,396)\end{array}$ & $\begin{array}{r}49,812 \\
(60,297)\end{array}$ & $\begin{array}{r}26,642 * * * \\
(24,931)\end{array}$ & $\begin{array}{r}45,218 * * * \\
(51,489)\end{array}$ & $\begin{array}{r}23,961 * * * \\
(25,754)\end{array}$ & $\begin{array}{r}34,971^{* *} \\
(40,169)\end{array}$ & $\begin{array}{r}27,671 * * * \\
(34,289)\end{array}$ & $\begin{array}{r}32,724 * * * \\
(41,831)\end{array}$ \\
\hline $\mathrm{N}$ & 66,955 & 25,383 & 12,003 & 4,914 & 5,021 & 2,069 & 14,546 & 3,019 \\
\hline
\end{tabular}

Table 1b

Family Incomes of Racial and Ethnic Groups in Miami/Ft. Lauderdale Metropolitan Area (Adults 18-65)

\begin{tabular}{|c|c|c|c|c|c|c|c|c|}
\hline \multirow[b]{2}{*}{$\begin{array}{l}\text { Racial/Ethnic } \\
\text { Group }\end{array}$} & \multirow[b]{2}{*}{ Total MSA } & \multirow[b]{2}{*}{$\begin{array}{c}\text { Non-Hispanic } \\
\text { White }\end{array}$} & \multirow[b]{2}{*}{$\begin{array}{c}\text { Non-Hispanic } \\
\text { Black }\end{array}$} & \multicolumn{3}{|c|}{ Cuban } & \multirow[b]{2}{*}{$\begin{array}{c}\text { Other } \\
\text { Hispanic }\end{array}$} & \multirow[b]{2}{*}{ Other } \\
\hline & & & & $\begin{array}{c}\text { Pre-1980 } \\
\text { Migrant }\end{array}$ & $\begin{array}{c}1980 \text { or } \\
\text { After } \\
\text { Migrant }\end{array}$ & U.S. Born & & \\
\hline $\begin{array}{l}\text { Family } \\
\text { Income }\end{array}$ & $\begin{array}{r}68,720 \\
(67,753)\end{array}$ & $\begin{array}{r}84,842 \\
(82,165)\end{array}$ & $\begin{array}{r}51,361 * * * \\
(41,434)\end{array}$ & $\begin{array}{r}82,589 \\
(74,208)\end{array}$ & $\begin{array}{r}51,071 * * * \\
(43,838)\end{array}$ & $\begin{array}{r}78,739 * * * \\
(62,310)\end{array}$ & $\begin{array}{r}56,371 * * * \\
(54,670)\end{array}$ & $\begin{array}{r}59,674 * * * \\
(59,775)\end{array}$ \\
\hline $\mathrm{N}$ & 66,955 & 25,383 & 12,003 & 4,914 & 5,021 & 2,069 & 14,546 & 3,019 \\
\hline
\end{tabular}

\footnotetext{
${ }^{1}$ Non-Hispanic White is the reference category. Significant differences from this category are noted by asterisks.

$* * * \mathrm{p}<0.001 ; * *<\mathrm{p} .01 ; * \mathrm{p}<0.05$, two tailed.
}

Source: IPUMS 2000; Note: Universe includes adults aged 18 - 64, who are not unemployed and whose annual income is greater than or equal to \$500. Raw Ns included; person weights used. Standard deviations in parenthesis. 
Table 2a

Personal Incomes of Working, Self-Employed, and Wage/Salaried Males by Racial and Ethnic Group in Miami/Ft. Lauderdale Metropolitan Area

\begin{tabular}{|c|c|c|c|c|c|c|c|c|}
\hline \multirow[b]{2}{*}{$\begin{array}{l}\text { Racial/Ethnic } \\
\text { Group }\end{array}$} & \multirow[b]{2}{*}{ Total MSA } & \multirow[b]{2}{*}{$\begin{array}{l}\text { Non- } \\
\text { Hispanic } \\
\text { White }\end{array}$} & \multirow[b]{2}{*}{$\begin{array}{c}\text { Non-Hispanic } \\
\text { Black }^{1}\end{array}$} & \multicolumn{3}{|c|}{ Cuban } & \multirow[b]{2}{*}{$\begin{array}{c}\text { Other } \\
\text { Hispanic }\end{array}$} & \multirow[b]{2}{*}{ Other } \\
\hline & & & & $\begin{array}{c}\text { Pre-1980 } \\
\text { Migrant }\end{array}$ & $\begin{array}{l}1980 \text { or } \\
\text { After } \\
\text { Migrant }\end{array}$ & U.S. Born ${ }^{1}$ & & \\
\hline Working Adults & $\begin{array}{r}45,010 \\
(57,377)\end{array}$ & $\begin{array}{r}61,712 \\
(72,504)\end{array}$ & $\begin{array}{r}28,929 * * * \\
(27,642)\end{array}$ & $\begin{array}{r}56,541 * * * \\
(63,132)\end{array}$ & $\begin{array}{r}26,918 * * * \\
(27,670)\end{array}$ & $\begin{array}{r}39,265 * * * \\
(46,748)\end{array}$ & $\begin{array}{r}32,414 * * * \\
(40,756)\end{array}$ & $\begin{array}{r}37,383 * * * \\
(48,084)\end{array}$ \\
\hline Self-Employed & $\begin{array}{r}64,968 \\
(86,719)\end{array}$ & $\begin{array}{r}80,948 \\
(97,159)\end{array}$ & $\begin{array}{r}39,255^{* * *} \\
(57,350)\end{array}$ & $\begin{array}{r}71,302 \\
(87,575)\end{array}$ & $\begin{array}{r}28,250 * * * \\
(34,865)\end{array}$ & $\begin{array}{r}65,594 \\
(84,173)\end{array}$ & $\begin{array}{r}49,033 * * * \\
(71,487)\end{array}$ & $\begin{array}{r}57,369 \\
(91,733)\end{array}$ \\
\hline Wage/Salaried & $\begin{array}{r}41,639 \\
(49,995)\end{array}$ & $\begin{array}{r}57,474 \\
(65,088)\end{array}$ & $\begin{array}{r}28,244 * * * \\
(24,281)\end{array}$ & $\begin{array}{r}52,523 * * \\
(53,955)\end{array}$ & $\begin{array}{r}26,647 * * * \\
(25,963)\end{array}$ & $\begin{array}{r}35,983 * * * \\
(38,525)\end{array}$ & $\begin{array}{r}30,254 * * * \\
(34,242)\end{array}$ & $\begin{array}{r}34,429 * * * \\
(36,706)\end{array}$ \\
\hline
\end{tabular}

\footnotetext{
${ }^{1}$ Non-Hispanic White is the reference category. Significant differences from this category are noted by asterisks.

$* * * \mathrm{p}<0.001 ; * *<\mathrm{p} .01 ; * \mathrm{p}<0.05$, two tailed.
}

Source: IPUMS 2000; Note: Universe includes adult males aged 18 - 64, who are not unemployed, and whose annual income is greater than or equal to $\$ 500$. Person-weights used; standard deviations in parenthesis. 
Table 2b

Family Incomes of Working, Self-Employed, and Wage Salaried Males

by Racial and Ethnic Group in Miami/Ft. Lauderdale Metropolitan Area

\begin{tabular}{|c|c|c|c|c|c|c|c|c|}
\hline \multirow[b]{2}{*}{$\begin{array}{l}\text { Racial/Ethnic } \\
\text { Group }\end{array}$} & \multirow[b]{2}{*}{ Total MSA } & \multirow[b]{2}{*}{$\begin{array}{l}\text { Non- } \\
\text { Hispanic } \\
\text { White }\end{array}$} & \multirow[b]{2}{*}{$\begin{array}{l}\text { Non-Hispanic } \\
\text { Black }^{1}\end{array}$} & \multicolumn{3}{|c|}{ Cuban } & \multirow[b]{2}{*}{$\begin{array}{c}\text { Other } \\
\text { Hispanic }\end{array}$} & \multirow[b]{2}{*}{ Other } \\
\hline & & & & $\begin{array}{l}\text { Pre-1980 } \\
\text { Migrant }\end{array}$ & $\begin{array}{c}1980 \text { or } \\
\text { After } \\
\text { Migrant }\end{array}$ & U.S. Born & & \\
\hline Self-Employed & $\begin{array}{r}90,618 \\
(100,842)\end{array}$ & $\begin{array}{r}106,667 \\
(110,504)\end{array}$ & $\begin{array}{r}60,443 * * * \\
(64,862)\end{array}$ & $\begin{array}{r}105,921 \\
(108,997)\end{array}$ & $\begin{array}{r}53,545 * * * \\
(52,097)\end{array}$ & $\begin{array}{r}94,683 \\
(92,853)\end{array}$ & $\begin{array}{r}71,671 * * * \\
(85,701)\end{array}$ & $\begin{array}{r}79,990 * * \\
(111,365)\end{array}$ \\
\hline Wage/Salaried & $\begin{array}{r}67,102 \\
(62,767)\end{array}$ & $\begin{array}{r}84,162 \\
(78,094)\end{array}$ & $\begin{array}{r}52,589 * * * \\
(40,224)\end{array}$ & $\begin{array}{r}82,363 \\
(66,334)\end{array}$ & $\begin{array}{r}49,410 * * * \\
(40,689)\end{array}$ & $\begin{array}{r}75,569 * * \\
(58,267)\end{array}$ & $\begin{array}{r}53,294 * * * \\
(46,670)\end{array}$ & $\begin{array}{r}55,868 * * * \\
(48,138)\end{array}$ \\
\hline
\end{tabular}

\footnotetext{
${ }^{1}$ Non-Hispanic White is the reference category. Significant differences from this category are noted by asterisks.

${ }^{* * *} \mathrm{p}<0.001 ; * *<\mathrm{p} .01 ;{ }^{*} \mathrm{p}<0.05$, two tailed.
}

Source: IPUMS 2000; Note: Universe includes adult males aged 18 - 64, who are not unemployed, and whose annual income is greater than or equal to $\$ 500$. Person-weights used; standard deviations in parenthesis. 
Table 3

Self-employment Rates among Males by Racial and Ethnic Group in Miami/Ft. Lauderdale Metropolitan Area (Adults 18-65)

\begin{tabular}{|c|c|c|c|c|c|c|c|c|}
\hline \multirow[b]{2}{*}{$\begin{array}{l}\text { Racial/Ethnic } \\
\text { Group }\end{array}$} & \multirow[b]{2}{*}{$\begin{array}{l}\text { Total } \\
\text { MSA }\end{array}$} & \multirow[b]{2}{*}{$\begin{array}{l}\text { Non- } \\
\text { Hispanic } \\
\text { White }\end{array}$} & \multirow[b]{2}{*}{$\begin{array}{l}\text { Non-Hispanic } \\
\text { Black }^{1}\end{array}$} & \multicolumn{3}{|c|}{ Cuban } & \multirow[b]{2}{*}{$\begin{array}{l}\text { Other } \\
\text { Hispanic }\end{array}$} & \multirow[b]{2}{*}{ Other } \\
\hline & & & & $\begin{array}{l}\text { Pre-1980 } \\
\text { Migrant }\end{array}$ & $\begin{array}{c}1980 \text { or } \\
\text { After } \\
\text { Migrant }\end{array}$ & U.S. Born & & \\
\hline Self-Employment & 0.14 & 0.18 & $0.06 * * *$ & $0.21 * * *$ & 0.17 & $0.11 * * *$ & $0.12 * * *$ & $0.13 * * *$ \\
\hline $\mathrm{N}$ & 35,285 & 13,780 & 5,430 & 2,398 & 3,077 & 1,051 & 7,872 & 1,677 \\
\hline
\end{tabular}

\footnotetext{
${ }^{1}$ Non-Hispanic White is the reference category. Significant differences from this category are noted by asterisks.

*** $\mathrm{p}<0.001 ; * *<\mathrm{p} .01 ; * \mathrm{p}<0.05$, two tailed.
}

Source: IPUMS 2000; Note: Universe includes adult males aged 18 - 64, who are not unemployed, and whose annual income is greater than or equal to $\$ 500$. Raw Ns included; person-weights used. 
Table 4a

Personal Incomes of Foreign-Born Males (18-65) Who Did Not Speak English Well or

At All in Miami/Ft. Lauderdale Metropolitan Area, 2000

\begin{tabular}{lrrrr}
\hline Racial/Ethnic Group & \multicolumn{1}{c}{ Total } & Other Hispanic & \multicolumn{1}{c}{ Cuban $^{1}$} & Non-Hispanic Other \\
\hline Working Adults & 21,679 & 20,753 & $22,939 * *$ & 20,331 \\
& $(24,212)$ & $(25,349)$ & $(23,166)$ & $(18,595)$ \\
& & & & 18,228 \\
Wage/Salaried & 20,639 & 19,455 & $22,365 * * *$ & $(12,439)$ \\
& $(19,780)$ & $(20,514)$ & $(18,200)$ & $144 ;$ \\
N (Working; & & & 1,$673 ;$ & 124 \\
Wage/Salaried) & 3,$907 ;$ & 1,$791 ;$ & 1,339 & 1,584 \\
\hline
\end{tabular}

Table 4b

Family Incomes of Foreign-Born Males (18-65) Who Did Not Speak English Well or At All in Miami/Ft. Lauderdale Metropolitan Area, 2000

\begin{tabular}{|c|c|c|c|c|}
\hline Racial/Ethnic Group & Total & Other Hispanic & Cuban $^{1}$ & "Non-Hispanic Other \\
\hline Working Adults & $\begin{array}{r}41,943 \\
(40,877)\end{array}$ & $\begin{array}{r}39,458 \\
(39,736)\end{array}$ & $\begin{array}{r}45,772 * * * \\
(44,042)\end{array}$ & $\begin{array}{r}35,818 \\
(25,329)\end{array}$ \\
\hline Wage/Salaried & $\begin{array}{r}40,635 \\
(37,366)\end{array}$ & $\begin{array}{r}38,160 \\
(35,922)\end{array}$ & $\begin{array}{r}44,596 * * * \\
(40,617)\end{array}$ & $\begin{array}{r}34,378 \\
(22,180)\end{array}$ \\
\hline $\begin{array}{l}\text { N (Working; } \\
\text { Wage/Salaried) }\end{array}$ & $\begin{array}{r}3,907 ; \\
3,320\end{array}$ & $\begin{array}{r}1,791 ; \\
1,584\end{array}$ & $\begin{array}{r}1,673 ; \\
1,339\end{array}$ & $\begin{array}{r}144 ; \\
124\end{array}$ \\
\hline
\end{tabular}

\footnotetext{
${ }^{1}$ Other Hispanic is the reference category. Significant differences from this category are noted by asterisks.

$* * * \mathrm{p}<0.001 ; * *<\mathrm{p} .01 ; * \mathrm{p}<0.05$, two tailed.

Source: IPUMS 2000; Note: Universe includes adult males aged 18 - 64, who are not unemployed and whose annual income is greater than or equal to \$500. Raw Ns included; person-weights used. Standard deviations in parenthesis.
} 
Table 4c

Personal Incomes of Foreign-Born Individuals (18-65) Who Did Not Speak English Well or At All in Miami/Ft. Lauderdale Metropolitan Area, 2000

\begin{tabular}{|c|c|c|c|c|}
\hline Racial/Ethnic Group & Total & Other Hispanic & Cuban $^{1}$ & Non-Hispanic Other \\
\hline Working Adults & $\begin{array}{r}18,687 \\
(22,322)\end{array}$ & $\begin{array}{r}17,568 \\
(21,542)\end{array}$ & $\begin{array}{r}20,080 * * * \\
(23,443)\end{array}$ & $\begin{array}{r}17,362 \\
(15,781)\end{array}$ \\
\hline Wage/Salaried & $\begin{array}{r}17,895 \\
(18,728)\end{array}$ & $\begin{array}{r}16,937 \\
(18,494)\end{array}$ & $\begin{array}{r}19,111^{* * *} \\
(18,494)\end{array}$ & $\begin{array}{r}16,156 \\
(11,530)\end{array}$ \\
\hline $\begin{array}{l}\text { N (Working; } \\
\text { Wage/Salaried) }\end{array}$ & $\begin{array}{r}6,922 ; \\
5,982\end{array}$ & $\begin{array}{r}3,253 \\
2,821\end{array}$ & $\begin{array}{r}2,806 ; \\
2,376\end{array}$ & $\begin{array}{r}250 ; \\
222\end{array}$ \\
\hline
\end{tabular}

Table 4d

Family Incomes of Foreign-Born Individuals (18-65) Who Did Not Speak English Well or At All in Miami/Ft. Lauderdale Metropolitan Area, 2000

\begin{tabular}{|c|c|c|c|c|}
\hline Racial/Ethnic Group & Total & Other Hispanic & Cuban $^{1}$ & Non-Hispanic Other \\
\hline Working Adults & $\begin{array}{r}42,981 \\
(43,602)\end{array}$ & $\begin{array}{r}41,390 \\
(45,018)\end{array}$ & $\begin{array}{r}46,083^{* * *} \\
(43,754)\end{array}$ & $\begin{array}{r}37,300^{*} \\
(25,704)\end{array}$ \\
\hline Wage/Salaried & $\begin{array}{r}41,806 \\
(40,280)\end{array}$ & $\begin{array}{r}40,198 \\
(42,177)\end{array}$ & $\begin{array}{r}44,906 * * * \\
(39,370)\end{array}$ & $\begin{array}{r}35,975 * \\
(23,319)\end{array}$ \\
\hline $\begin{array}{l}\text { N (Working; } \\
\text { Wage/Salaried) }\end{array}$ & $\begin{array}{r}6,922 ; \\
5,982\end{array}$ & $\begin{array}{r}3,253 ; \\
2,821\end{array}$ & $\begin{array}{r}2,806 ; \\
2,376\end{array}$ & $\begin{array}{r}250 ; \\
222\end{array}$ \\
\hline
\end{tabular}

\footnotetext{
${ }^{1}$ Other Hispanic is the reference category. Significant differences from this category are noted by asterisks.

$* * * \mathrm{p}<0.001 ; * *<\mathrm{p} .01 ; * \mathrm{p}<0.05$, two tailed.

Source: IPUMS 2000; Note: Universe includes adults aged 18 - 64, who are not unemployed and whose annual income is greater than or equal to \$500. Raw Ns included; person-weights used. Standard deviations in parenthesis.
} 
Table 5

Family Incomes of Immigrant Parents in Miami/Ft. Lauderdale Metropolitan Area

\begin{tabular}{|c|c|c|c|c|c|}
\hline & \multirow[b]{2}{*}{ Total Sample } & \multicolumn{2}{|c|}{ Nationality } & \multicolumn{2}{|c|}{ Cuban } \\
\hline & & Cuban $^{1}$ & Non-Cuban & Self-employed $^{2}$ & Other \\
\hline Family Income & $\begin{array}{r}40,218 \\
(38,334)\end{array}$ & $\begin{array}{r}47,517 * * * \\
(42,245)\end{array}$ & $\begin{array}{r}36,350 \\
(35,518)\end{array}$ & $\begin{array}{r}61,986 * * \\
(58,774)\end{array}$ & $\begin{array}{r}43,960 \\
(36,334)\end{array}$ \\
\hline $\mathrm{N}$ & 1,068 & 698 & 370 & 73 & 297 \\
\hline
\end{tabular}

\footnotetext{
${ }^{1}$ Non-Cuban is the reference category. Significant differences from this category are noted by asterisks.

${ }^{2}$ Non-self-employed is the reference category.

*** $\mathrm{p}<0.001 ; * *<\mathrm{p} .01 ; * \mathrm{p}<0.05$, two tailed.
}

Source: CILS Parental Survey; Standard deviation in parenthesis. 


\section{Table 6}

Regressions of Family Income on Ethnicity and Selected Variables (Adults 18-64)

\begin{tabular}{|c|c|c|}
\hline & $\bar{I}$ & II \\
\hline \multicolumn{3}{|l|}{ Ethnicity: } \\
\hline Cuban $^{\mathrm{a}}$ & $\begin{array}{r}-9511.28 * * * \\
(796.40)\end{array}$ & \\
\hline Pre-1980 Cuban & & $\begin{array}{c}212.53 \\
(1206.35)\end{array}$ \\
\hline 1980 or After Cuban & & $\begin{array}{r}-23552.77 * * * \\
(876.18)\end{array}$ \\
\hline U.S.-born Cuban & & $\begin{array}{c}114.91 \\
(1580.00)\end{array}$ \\
\hline Black & $\begin{array}{r}-21608.99 * * * \\
(642.99)\end{array}$ & $\begin{array}{c}-21912.73^{* * * *} \\
(641.92)\end{array}$ \\
\hline Hispanic & $\begin{array}{r}-19352.02 * * * \\
(715.17)\end{array}$ & $\begin{array}{c}-19680.03^{* * * *} \\
(714.77)\end{array}$ \\
\hline Other & $\begin{array}{r}-19793.26 * * * \\
(1271.88)\end{array}$ & $\begin{array}{c}-20046.82 * * * \\
(1271.86)\end{array}$ \\
\hline Female & $\begin{array}{r}-1925.97 * * * \\
(529.81)\end{array}$ & $\begin{array}{c}-2342.27 * * * \\
(529.07)\end{array}$ \\
\hline Age & $\begin{array}{r}392.40 * * \\
(147.95)\end{array}$ & $\begin{array}{l}442.76^{* *} \\
(148.60)\end{array}$ \\
\hline Age & $\begin{array}{r}-0.93 \\
(1.86)\end{array}$ & $\begin{array}{l}-1.79 \\
(1.86)\end{array}$ \\
\hline \multicolumn{3}{|l|}{ Education: } \\
\hline High School & $\begin{array}{r}7031.37 * * * \\
(698.97)\end{array}$ & $\begin{array}{c}6269.24 * * * \\
(697.53)\end{array}$ \\
\hline Some College & $\begin{array}{r}17832.03 * * * \\
(721.40)\end{array}$ & $\begin{array}{c}16139.94 * * * \\
(723.35)\end{array}$ \\
\hline College & $\begin{array}{r}37975.68 * * * \\
(981.78)\end{array}$ & $\begin{array}{r}36265.05^{* * * *} \\
(980.72)\end{array}$ \\
\hline Post-Graduate & $\begin{array}{r}60470.47 * * * \\
(1479.38)\end{array}$ & $\begin{array}{c}58872.11^{* * * *} \\
\quad(1471.76)\end{array}$ \\
\hline Self-Employed & $\begin{array}{r}14167.01^{* * *} \\
(1198.81)\end{array}$ & $\begin{array}{c}14133.69 * * * \\
(1194.73)\end{array}$ \\
\hline Intercept & $\begin{array}{r}44109.86 * * * \\
(2882.71)\end{array}$ & $\begin{array}{c}45180.10^{* * * *} \\
(2898.06)\end{array}$ \\
\hline $\mathrm{N}$ & 66,955 & 66,955 \\
\hline $\mathrm{R}^{2}$ & 0.12 & 0.12 \\
\hline
\end{tabular}

${ }^{\mathrm{a}}$ Non-Hispanic White is the reference category.

Source: IPUMS 2000 (5\% microsample). Standard deviations in parentheses.

Note: Universe includes adults aged 18-64, who are not unemployed and whose annual income is greater than or equal to $\$ 500$. Raw $N$ values included; person-weights used. ${ }^{* * *} \mathrm{p}<0.001 ;{ }^{* *} \mathrm{p}<0.01$; ${ }^{*} \mathrm{p}<0.05$, two tailed. 


\section{Table 7}

\section{Regression of Family Income on Ethnicity and Selected Variables Substituting Work Experience for Age}

\begin{tabular}{|c|c|c|}
\hline & Adults (18-64) & Males (18-64) \\
\hline \multicolumn{3}{|l|}{ Ethnicity: ${ }^{\mathrm{a}}$} \\
\hline Pre-1980 Cuban & $\begin{array}{c}2023.88 \\
(1220.47)\end{array}$ & $\begin{array}{c}3849.55^{*} \\
(1777.46)\end{array}$ \\
\hline 1980 or After Cuban & $\begin{array}{c}-14956.88^{* * *} \\
(1027.94)\end{array}$ & $\begin{array}{c}-16442.62^{* * * *} \\
(1381.96)\end{array}$ \\
\hline U.S.-born Cuban & $\begin{array}{c}-222.71 \\
(1574.38)\end{array}$ & $\begin{array}{c}-372.66 \\
(2272.18)\end{array}$ \\
\hline Black & $\begin{array}{c}-19062.42^{* * *} \\
(676.70)\end{array}$ & $\begin{array}{c}-17100.27^{* * * *} \\
(974.96)\end{array}$ \\
\hline Hispanic & $\begin{array}{c}-14163.78^{* * * *} \\
(813.21)\end{array}$ & $\begin{array}{c}-15565.28^{* * *} \\
(1115.40)\end{array}$ \\
\hline Other & $\begin{array}{c}-14091.57^{* * *} \\
(1345.03)\end{array}$ & $\begin{array}{c}-15856.60 * * * \\
(1834.92)\end{array}$ \\
\hline Female & $\begin{array}{c}-2408.99 * * * \\
(528.30)\end{array}$ & \\
\hline Work Experience (US) ${ }^{\mathrm{b}}$ & $\begin{array}{l}940.46 * * * \\
(58.77)\end{array}$ & $\begin{array}{l}934.68 * * * \\
(100.78)\end{array}$ \\
\hline Work Experience (US) & $\begin{array}{l}-15.81 * * * \\
(1.89)\end{array}$ & $\begin{array}{c}-13.00 * * * \\
(2.65)\end{array}$ \\
\hline \multicolumn{3}{|l|}{ Education: $^{\mathrm{c}}$} \\
\hline High School & $\begin{array}{l}5787.45^{* * *} \\
(697.25)\end{array}$ & $\begin{array}{l}\text { 5109.78*** } \\
(893.68)\end{array}$ \\
\hline Some College & $\begin{array}{c}15452.91 * * * \\
(717.47)\end{array}$ & $\begin{array}{c}14750.29 * * * \\
(938.03)\end{array}$ \\
\hline College & $\begin{array}{c}36585.79 * * * \\
(977.00)\end{array}$ & $\begin{array}{l}37062.47 * * * \\
(1295.85)\end{array}$ \\
\hline Post-Graduate & $\begin{array}{l}60334.30^{* * * *} \\
(1469.41)\end{array}$ & $\begin{array}{l}66736.50 * * * \\
(2010.92)\end{array}$ \\
\hline Self-Employed ${ }^{\mathrm{d}}$ & $\begin{array}{l}14869.66^{* * * *} \\
(1189.95)\end{array}$ & $\begin{array}{l}15281.24 * * * \\
(1451.51)\end{array}$ \\
\hline Intercept & $\begin{array}{l}50467.92 * * * \\
(1017.30)\end{array}$ & $\begin{array}{l}49398.98 * * * \\
(1371.06)\end{array}$ \\
\hline $\mathrm{N}$ & 66,955 & 35,285 \\
\hline $\mathrm{R}^{2}$ & 0.13 & 0.15 \\
\hline
\end{tabular}

\footnotetext{
${ }^{\text {a }}$ Non-Hispanic white is the reference category.

${ }^{\mathrm{b}}$ See text for definition of this variable.

${ }^{\mathrm{c}}$ Less than high school is the reference category.

${ }^{\mathrm{d}}$ Wage/salaried worker is the reference category.

Source: IPUMS 2000 (5\% microsample). Standard deviations in parentheses.

Note: Universe includes adults aged 18 - 64, who are not unemployed, and whose annual income is greater than or equal to $\$ 500$. Raw Ns included; person weight used.

${ }^{* * *} \mathrm{p}<0.001$; ${ }^{* *} \mathrm{p}<0.01 ;{ }^{*} \mathrm{p}<0.05$; two tailed
} 
Table 8

Within-Group Regression of Family Income on Ethnicity and Selected Variables (Adults 18-64)

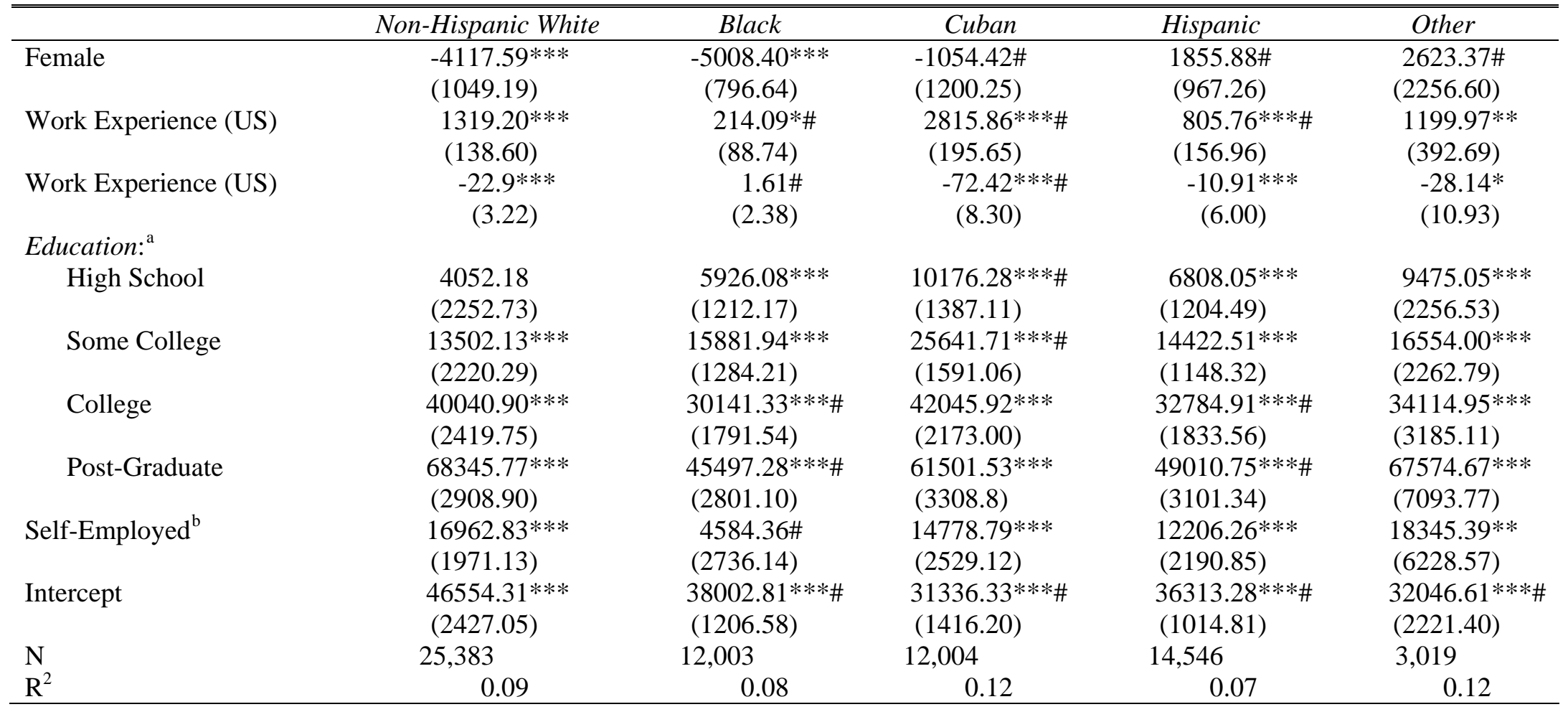

\footnotetext{
${ }^{a}$ Less than high school is the reference category.

${ }^{\mathrm{b}}$ Wage/Salaried individuals is the reference category.

${ }^{* * *} \mathrm{p}<0.001 ;{ }^{* *} \mathrm{p}<0.01 ;{ }^{*} \mathrm{p}<0.05$; two-tailed

\# = Significantly different from Non-Hispanic whites.

Source: IPUMS 2000 (5\%) microsample). Standard deviations are in parentheses.

Note: Universe includes adults aged 18 to 64, who are not unemployed, and whose annual income is greater than or equal to \$500. Raw Ns included; person weight used.
} 
Table 9

Within-Group Regression of Family Income on Ethnicity and Selected Variables: Non-Hispanic Whites and Disaggregated Cuban Population

\begin{tabular}{|c|c|c|c|c|}
\hline & Non-Hispanic White & Pre-1980 Cuban & $1980+$ Cuban & U.S.-born Cuban \\
\hline \multirow[t]{2}{*}{ Female } & $-4117.59 * * *$ & $-5024.23 *$ & 2101.20\# & -1563.30 \\
\hline & $(1049.19)$ & $(2160.30)$ & $(1424.20)$ & $(3036.46)$ \\
\hline \multirow[t]{2}{*}{ Work Experience (US) } & $1319.20 * * *$ & $2624.27 * * * \#$ & $1608.37 *$ & 749.24 \\
\hline & $(138.60)$ & $(619.31)$ & $(687.42)$ & $(518.04)$ \\
\hline \multirow[t]{2}{*}{ Work Experience (US) $^{2}$} & $-22.9 * * *$ & $-61.96 * * \#$ & $-172.32 * * \#$ & -16.31 \\
\hline & $(3.22)$ & $(18.95)$ & $(62.47)$ & (16.29) \\
\hline \multicolumn{5}{|l|}{ Education: ${ }^{\mathrm{a}}$} \\
\hline \multirow[t]{2}{*}{ High School } & 4052.18 & 16151.95***\# & $3537.81 *$ & 8916.98 \\
\hline & $(2252.73)$ & $(2904.91)$ & $(1672.30)$ & $(5391.65)$ \\
\hline \multirow[t]{2}{*}{ Some College } & $13502.13 * * *$ & $31908.14^{* * * * \#}$ & $19179.55 * * *$ & $22576.09 * * *$ \\
\hline & $(2220.29)$ & (3167.08) & $(2234.00)$ & $(5268.87)$ \\
\hline \multirow[t]{2}{*}{ College } & $40040.90 * * *$ & $58307.49 * * * \#$ & $16689.70 * * * \#$ & $42263.08 * * *$ \\
\hline & $(2419.75)$ & $(4108.60)$ & $(2957.62)$ & $(5888.30)$ \\
\hline \multirow[t]{2}{*}{ Post-Graduate } & $68345.77 * * *$ & $86260.38 * * * \#$ & $24439.22 * * * \#$ & $62305.33 * * *$ \\
\hline & $(2908.90)$ & $(5801.42)$ & $(3415.14)$ & $(9110.61)$ \\
\hline \multirow[t]{2}{*}{ Self-Employed ${ }^{\mathrm{b}}$} & $16962.83^{* * *}$ & $23032.79 * * *$ & $5900.75 * \#$ & 11171.43 \\
\hline & $(1971.13)$ & $(4509.87)$ & $(2537.09)$ & (7328.04) \\
\hline \multirow[t]{2}{*}{ Intercept } & $46554.31 * * *$ & $-24690.68 * * * \#$ & $39608.79 * * * \#$ & $46889.03^{* *}$ \\
\hline & $(2427.05)$ & (5703.16) & $(1734.45)$ & $(5644.14)$ \\
\hline $\mathrm{N}$ & 25,383 & 4,914 & 5,021 & 2.069 \\
\hline $\mathrm{R}^{2}$ & 0.09 & 0.11 & 0.04 & 0.08 \\
\hline
\end{tabular}

\footnotetext{
${ }^{a}$ Less than high school is the reference category.

${ }^{\mathrm{b}}$ Wage/Salaried individuals is the reference category.

${ }^{* * *} \mathrm{p}<0.001 ;{ }^{* *} \mathrm{p}<0.01 ;{ }^{*} \mathrm{p}<0.05$; two-tailed.

\# = Significantly different than Non-Hispanic whites.

Source: IPUMS 2000 (5\%) microsample). Standard deviations in parentheses.

Note: Universe includes adults aged 18 to 64, who are not unemployed, and whose annual income is greater than or equal to \$500. Raw Ns included; person weight used.
} 


\section{Table 10}

Determinants of Self-Employment in Miami-Ft. Lauderdale, 2000 (Adults 18-64) ${ }^{\mathrm{a}}$

\begin{tabular}{|c|c|c|}
\hline & $I$ & II \\
\hline \multicolumn{3}{|l|}{ Ethnicity: ${ }^{\mathrm{b}}$} \\
\hline \multirow[t]{2}{*}{ Cuban } & $1.0975 *$ & \\
\hline & $(0.0425)$ & \\
\hline \multirow[t]{2}{*}{ Pre-1980 Cuban } & & $1.2844^{* * *}$ \\
\hline & & $(0.0621)$ \\
\hline \multirow[t]{2}{*}{1980 or After Cuban } & & 1.1072 \\
\hline & & $(0.0646)$ \\
\hline \multirow[t]{2}{*}{ U.S.-born Cuban } & & $0.6387 * * *$ \\
\hline & & $(0.0572)$ \\
\hline \multirow[t]{2}{*}{ Black } & $0.3724 * * *$ & $0.3716^{* * *}$ \\
\hline & $(0.0190)$ & $(0.0191)$ \\
\hline \multirow[t]{2}{*}{ Hispanic } & $0.9029 * *$ & $0.8960 * *$ \\
\hline & $(0.0366)$ & $(0.0371)$ \\
\hline \multirow[t]{2}{*}{ Other } & $0.8422 * *$ & $0.8352 * *$ \\
\hline & $(0.0589)$ & $(0.0588)$ \\
\hline \multirow[t]{2}{*}{ Female } & $0.4931 * * *$ & $0.4925 * * *$ \\
\hline & $(0.0139)$ & $(0.0138)$ \\
\hline \multirow[t]{2}{*}{ Work Experience (US) } & $1.0076^{*}$ & 1.0057 \\
\hline & $(0.0034)$ & $(0.0037)$ \\
\hline \multirow[t]{2}{*}{ Work Experience (US) } & $1.0002 * *$ & $1.0002 * *$ \\
\hline & $(0.0001)$ & $(0.0001)$ \\
\hline \multicolumn{3}{|l|}{ Education: ${ }^{c}$} \\
\hline \multirow[t]{2}{*}{ High School } & 0.9136 & 0.9199 \\
\hline & $(0.0432)$ & $(0.0436)$ \\
\hline \multirow[t]{2}{*}{ Some College } & $0.8010^{* * *}$ & $0.8138 * * *$ \\
\hline & $(0.0380)$ & $(0.0387)$ \\
\hline \multirow[t]{2}{*}{ College } & $0.9001^{*}$ & 0.9131 \\
\hline & $(0.0467)$ & $(0.0475)$ \\
\hline \multirow[t]{2}{*}{ Post-Graduate } & $1.3611^{* * *}$ & $1.3752^{* * *}$ \\
\hline & $(0.0732)$ & $(0.0741)$ \\
\hline $\mathrm{N}$ & 66,955 & 66,955 \\
\hline Pseudo $\mathrm{R}^{2}$ & 0.04 & 0.04 \\
\hline Wald $\mathrm{Chi}^{2}$ & 1400.57 & 1465.33 \\
\hline
\end{tabular}

\footnotetext{
${ }^{a}$ Logistic regression, net odds-ratios to the fourth digit. Standard deviations in parentheses.

${ }^{\mathrm{b}}$ Non-Hispanic White is the reference category.

${ }^{\mathrm{c}}$ Less than high school is the reference category.

Universe includes adults aged $18-64$, who are not unemployed, and whose annual income is greater than or equal to $\$ 500$. Raw Ns included; person weight used.

${ }^{* * *} \mathrm{p}<0.01 ; * * \mathrm{p}<0.01 ;{ }^{*} \mathrm{p}<0.05$; two tailed.

Source: IPUMS 2000 (5\% microsample)
} 
Table 11

Within-Group Determinants of Self-Employment in Miami-Ft. Lauderdale, 2000 (Adults 18-64) ${ }^{\mathrm{a}}$

\begin{tabular}{|c|c|c|c|c|c|c|c|}
\hline & White & Black & $\begin{array}{l}\text { Pre-1980 } \\
\text { Cuban }\end{array}$ & $1980+$ Cuban & U.S.-born Cuban & Other Hispanic & Other \\
\hline Female & $\begin{array}{r}0.4375 * * * \\
(0.0183)\end{array}$ & $\begin{array}{c}0.5714 * * * \# \\
(0.0548)\end{array}$ & $\begin{array}{r}0.3628 * * * \\
(0.0328)\end{array}$ & $\begin{array}{c}0.3399 * * * \# \\
(0.0382)\end{array}$ & $\begin{array}{l}0.3439 * * * \\
(0.0684)\end{array}$ & $\begin{array}{c}0.7943 * * * \# \\
(0.0471)\end{array}$ & $\begin{array}{r}0.4932 * * * \\
(0.0679)\end{array}$ \\
\hline $\begin{array}{l}\text { Work Experience } \\
\text { (US) }\end{array}$ & $\begin{array}{r}1.0103 \\
(0.0056)\end{array}$ & $\begin{array}{c}0.9764 * \# \\
(0.0101)\end{array}$ & $\begin{array}{c}0.9899 \\
(0.0234)\end{array}$ & $\begin{array}{l}1.211^{* * * * \#} \\
(0.0616)\end{array}$ & $\begin{array}{c}1.2154 * * * \# \\
(0.0384)\end{array}$ & $\begin{array}{c}0.9972 \\
(0.0098)\end{array}$ & $\begin{array}{c}0.9904 \\
(0.0168)\end{array}$ \\
\hline $\begin{array}{l}\text { Work Experience } \\
\text { (US) }\end{array}$ & $\begin{array}{r}1.0001 \\
(0.0001)\end{array}$ & $\begin{array}{c}1.0009 * * * \# \\
(0.0003)\end{array}$ & $\begin{array}{c}1.0010 \\
(0.0008)\end{array}$ & $\begin{array}{l}0.9855 * * \# \\
(0.0052)\end{array}$ & $\begin{array}{l}0.9960 * * * \\
(0.0010)\end{array}$ & $\begin{array}{c}1.0001 \\
(0.0003)\end{array}$ & $\begin{array}{c}1.0001 \\
(0.0004)\end{array}$ \\
\hline \multicolumn{8}{|l|}{ Education: ${ }^{\mathrm{b}}$} \\
\hline High School & $\begin{array}{r}1.0828 \\
(0.1128)\end{array}$ & $\begin{array}{c}1.1229 \\
(0.1520)\end{array}$ & $\begin{array}{c}0.7515^{*} \# \\
(0.1114)\end{array}$ & $\begin{array}{c}0.8660 \\
(0.1122)\end{array}$ & $\begin{array}{l}0.3999 * * \# \\
(0.1535)\end{array}$ & $\begin{array}{c}0.9567 \\
(0.0841)\end{array}$ & $\begin{array}{c}1.3862 \\
(0.3190)\end{array}$ \\
\hline Some College & $\begin{array}{r}1.0257 \\
(0.1051)\end{array}$ & $\begin{array}{c}0.7683 \\
(0.1158)\end{array}$ & $\begin{array}{r}0.7254^{*} \\
(0.1064)\end{array}$ & $\begin{array}{c}0.5783 * * * \# \\
(0.0931)\end{array}$ & $\begin{array}{c}0.5452 \# \\
(0.1899)\end{array}$ & $\begin{array}{l}0.8164 * \\
(0.0732)\end{array}$ & $\begin{array}{r}1.7405^{*} \# \\
(0.3960)\end{array}$ \\
\hline College & $\begin{array}{r}1.1942 \\
(0.1251)\end{array}$ & $\begin{array}{c}0.8778 \\
(0.1766)\end{array}$ & $\begin{array}{c}0.6598 * \# \\
(0.1144)\end{array}$ & $\begin{array}{l}0.5184^{* * *} \\
(0.1138)\end{array}$ & $\begin{array}{l}0.4668 * \# \\
(0.1789)\end{array}$ & $\begin{array}{c}0.9948 \\
(0.1031)\end{array}$ & $\begin{array}{c}1.2036 \\
(0.3010)\end{array}$ \\
\hline Post-Graduate & $\begin{array}{r}1.7088 * * * \\
(0.1823)\end{array}$ & $\begin{array}{c}1.3166 \\
(0.2853)\end{array}$ & $\begin{array}{c}1.4737^{*} \\
(0.2590)\end{array}$ & $\begin{array}{c}0.9572 \# \\
(0.1936)\end{array}$ & $\begin{array}{c}1.6421 \\
(0.6362)\end{array}$ & $\begin{array}{c}1.3070 * \\
(0.1473)\end{array}$ & $\begin{array}{r}2.0515 * * \# \\
(0.5325)\end{array}$ \\
\hline $\mathrm{N}$ & 25,383 & 12,003 & 4,914 & 5,021 & 2,069 & 14,546 & 3,019 \\
\hline Pseudo $\mathrm{R}^{2}$ & 0.03 & 0.02 & 0.05 & 0.05 & 0.10 & 0.001 & 0.03 \\
\hline Wald Chi ${ }^{2}$ & 552.16 & 84.32 & 163.67 & 150.57 & 93.93 & 39.21 & 50.38 \\
\hline
\end{tabular}

\footnotetext{
${ }^{\text {a }}$ Logistic regression, net odds-ratios to the fourth digit. Standard deviations in parentheses.

${ }^{\mathrm{b}}$ Less than high school is the reference category.

Universe includes adult males aged 18 - 64, who are not unemployed, and whose annual income is greater than or equal to \$500. Raw Ns included; person weight used.

${ }^{* * *} \mathrm{p}<0.01 ;{ }^{* *} \mathrm{p}<0.01 ;{ }^{*} \mathrm{p}<0.05$; two tailed; \# = Significantly different than Non-Hispanic whites.

Source: IPUMS 2000 (5\% microsample)
} 